\title{
Ewa Andrysiak
}

Katedra Informatologii i Bibliologii

Uniwersytet Łódzki

e-mail: eandrysiak@kp.kalisz.pl

\section{Ewa Obała}

Państwowa Wyższa Szkoła Zawodowa

im. Prezydenta S. Wojciechowskiego w Kaliszu

e-mail: ewa132@autograf.pl

\section{Ogólnopolska konferencja naukowa \\ [ „Kultura książki w humanistyce współczesnej” (Wrocław, 23-24 listopada 2016 r.)}

\section{DOI: http://dx.doi.org/10.18778/0860-7435.24.15}

W dniach 23-24 listopada 2016 r., w sali Oratorium Marianum Uniwersytetu Wrocławskiego, odbyła się Ogólnopolska Konferencja Naukowa pt. „Kultura książki w humanistyce współczesnej”, zorganizowana z okazji 60-lecia Instytutu Informacji Naukowej i Bibliotekoznawstwa Uniwersytetu Wrocławskiego. Patronat honorowy objęli nad nią prof. dr hab. Adam Jezierski (rektor Uniwersytetu Wrocławskiego) i prof. dr hab. Marcin Cieński (dziekan Wydziału Filologicznego UWr).

Sesję jubileuszowa, którą rozpoczęła od powitania zebranych dyrektor IBiIN prof. nadzw. dr hab. Bożena Koredczuk, poprowadziła dr Kamila Augustyn. Jako pierwszy głos zabrał rektor UWr, gratulując pracownikom wkładu pracy i dorobku naukowego, dzięki którym Instytut cieszy się bardzo dobrą opinią. Z kolei dziekan Wydziału Filologicznego zwrócił uwagę na piękna tradycję, znakomitą współczesność i dobre perspektywy, a także na znaczenie bibliotekoznawstwa oraz rolę książki w naukach humanistycznych. Osiagnięcia ostatniego dziesięciolecia Instytutu przedstawiła prof. B. Koredczuk, która 


\section{Ewa Andrysiak, Ewa Obała}

podkreśliła, że zmieniło się jego oblicze zarówno pod względem wyglądu (wyremontowany na zewnątrz i wewnątrz budynek stwarza dobre warunki pracy i nauki), jak i pod względem naukowym i edukacyjnym (poszerzenie oferty edukacyjnej, prowadzenie badań naukowych, dzięki którym coraz lepiej przekazywana jest wiedza).

Ważnym punktem sesji jubileuszowej było wręczenie Złotego Medalu Uniwersytetu Wrocławskiego prof. Krzysztofowi Migoniowi, którego dokonał rektor UWr, a poprzedziła to wydarzenie laudacja na cześć Profesora - znanego i cenionego bibliologa, którą wygłosiła prof. B. Koredczuk. Dziękując za ten zaszczyt prof. K. Migoń stwierdził, że traktuje to jako wyróżnienie nie tylko dla niego, ale dla całego zespołu, z którego wyrósł, z którym pracował i dla dyscypliny, którą przez dziesięciolecia uprawiał.

Niespodzianką obchodów jubileuszowych był krótki koncert w wykonaniu rektora UWr, który zagrał na słynnych organach Adama Horatiusa Caspariniego z 1718 roku.

W dalszej części sesji jubileuszowej kierownicy zakładów IINiB UWr prezentowali ich osiagnięcia naukowe i dydaktyczne, przypominając historię powstania, strukturę, sylwetki kolejnych kierowników, kierunki badawcze, konferencje, wybrane publikacje pracowników, wydawnictwa, czasopisma. O Zakładzie Teorii i Historii Książki mówiła prof. Bożena Koredczuk, Zakładzie Bibliotekoznawstwa - prof. Bogumiła Staniów, Zakładzie Bibliografii i Informacji Naukowej - dr hab. Aneta Firlej-Buzon, a o Zakładzie Książki Współczesnej i Edytorstwa - dr hab. Małgorzata Góralska.

Jubileusz IINiB UWr był okazją do wręczenia nagród laureatom IV edycji konkursu „Studenci Projektuja”, którego tematem było przygotowanie oprawy graficznej materiałów konferencyjnych. Nagrody zwycięzcom oraz wyróżnionym wręczała kierownik konkursu, dr Ewa Repucho.

Z okazji jubileuszu 60-lecia IINiB nadeszło wiele listów gratulacyjnych z całej Polski, m.in. od Elżbiety Stefańczyk (przewodniczącej Stowarzyszenia Bibliotekarzy Polskich), Grażyny Piotrowicz (dyrektor Biblioteki Uniwersyteckiej we Wrocławiu), od Instytutu Bibliotekoznawstwa i Informacji Naukowej na Wydziale Filologicznym Uniwersytetu Komeńskiego w Bratysławie. $\mathrm{Na}$ ręce prof. Bożeny Koredczuk gratulacje złożyli przybyli goście i uczestnicy konferencji, reprezentujący wiele uczelni, placówek bibliologicznych, bibliotek i instytucji, m.in. prof. Krzysztof Migoń, który przekazał także gratulacje od Rosyjskiej Akademii Nauk, prof. Dariusz Kuźmina z Wydziału Dziennikarstwa, Informacji i Bibliologii UW, Aušra Navickiené z Uniwersytetu w Wilnie, prof. Remigiusz Sapa z Instytutu Informacji Naukowej i Bibliotekoznawstwa UJ, prof. UMK dr hab. Ewa Głowacka z Instytutu Informacji Na- 


\section{Ogólnopolska konferencja naukowa...}

ukowej i Bibliologii Uniwersytetu Mikołaja Kopernika w Toruniu, Instytut Dziennikarstwa i Informacji Uniwersytet J. Kochanowskiego w Kielcach, dr hab. Michał Rogoż z Instytutu Nauk o Informacji Uniwersytetu Pedagogicznego w Krakowie, Marta Špániová z Uniwersytetu Komeńskiego w Bratysławie, prof. Mariola Antczak z Katedry Informatologii i Bibliologii UŁ, dr hab. Jacek Tomaszczyk z Instytutu Bibliotekoznawstwa i Informacji Naukowej UŚ, dr Andrzej Buck z Wojewódzkiej i Miejskiej Biblioteki Publicznej im. C. Norwida w Zielonej Górze.

Jak przystało na jubileusz, nie zabrakło wystawy poświęconej IINiB, której prezentacji dokonał dr Rafał Werszler oraz tortu i symbolicznego toastu.

Po sesji jubileuszowej obrady plenarne toczyły się w sali Oratorium Marianum pod hasłem „Kultura książki w badaniach nauk humanistycznych”, którym przewodniczył prof. dr hab. Dariusz Kuźmina. Wystapienia rozpoczął prof. K. Migoń (Uniwersytet Wrocławski) referatem Kultura ksiqżki jako pržedmiot badań multidyscyplinarnych, w którym przedstawił książkę jako narzędzie kultury i jako najdoskonalszy instrument komunikacji pokonującej bariery. Stwierdził, że nauka o książce to wyodrębniona dyscyplina nauk humanistycznych, a podejście multidyscyplinarne pozwala na pogłębienie poznania kultury tejże książki. Tematem wystapienia dr hab. Jolanty Gwioździk (Uniwersytet Śląski w Katowicach) była Zakonna kultura ksiażki w bumanistyce europejskiej. Projekty i kierunki badawcze. Prelegentka omówiła kierunki badań nad obecnościa i rola książki w kulturze zakonnej na przestrzeni dziejów oraz przedstawiła najnowsze projekty cyfrowe, utrwalające i promujące dziedzictwo umysłowe zakonów. Kolejny prelegent, dr hab. Zbigniew Osiński (Uniwersytet M. Curie-Skłodowskiej w Lublinie), mówił o Modelach ksiażek / prac naukowych w koncepcjach i praktyce cyfrowych humanistów. Na podstawie analizy literatury naukowej i eksploracji zasobów Internetu prezentował różnorodne formy książek, m.in. cyfrowe, interaktywne, stanowiące połączenie tekstu z multimediami, bazujace na wizualizacjach i infografikach, hipertekstowe, tzw. rozproszone, bez granic, przedstawił także wypowiedzi na ten temat cyfrowych humanistów (R. Darnton i E. Ayers, R. Rosenstone i H. White, czy D. Staley) i dydaktyków. Przedmiotem rozważań dr hab. Bogumiły Staniów (prof. Uniwersytetu Wrocławskiego) była Kategoria ksiażki dla drieci i mtodzięzy we wspótczesnym polskim literaturoznawstwie. Badaniu prof. Staniów poddała wydane po 2000 r. tytuły i podtytuły monografii i prac zbiorowych, także tytuły ich rozdziałów oraz, rozbudowane czasem metodologicznie, wstępy. Z tematem Caytelnictwo wspótcześnie: intuicje caytelników i pytania badacay wystapiła dr hab. Małgorzata Kisilowska (Uniwersytet Warszawski). Badaczka wzięła pod uwagę wyniki badań statystycznych Biblioteki Narodowej i Pol- 


\section{Ewa Andrysiak, Ewa Obała}

skiej Izby Książki z lat 2014-2016 pokazujące ilość i jakość wypożyczanych książek wskazujące na to, co czytamy. Zajęła się jednak przede wszystkim danymi pozyskanymi na podstawie ankiet i wywiadów z czytelnikami, którzy odpowiadali na pytania z czym czytanie im się kojarzy; wyniki tych badań są ilustracja zmian zachodzących w kulturze czytelniczej. Ostatni w sesji plenarnej referat pt. Akceptacja «otwartej cyfrowej humanistyki» - praypadek Uniwersytetu Jagiellońskiego przygotowały dr hab. Maria Próchnicka i dr Małgorzata Janiak (Uniwersytet Jagielloński). Autorki przedstawiły wyniki badań przeprowadzonych wśród przedstawicieli nauk humanistycznych: pracowników naukowych, dydaktycznych, studentów i doktorantów UJ. Celem analiz była identyfikacja stanu świadomości i postaw członków środowiska akademickiego, dotyczących otwartego dostępu do zasobów nauki, ocena gotowości członków tego środowiska do otwartego udostępnienia publikacji, ocena stopnia korzystania $\mathrm{z}$ zasobów nauki w otwartym dostępie, rodzajów zasobów w otwartym dostępie $\mathrm{i}$ innych.

Z zaplanowanych po przerwie obrad trzech sekcji, odwołany został panel III pt. „Kultura książki w środowiskach wyznaniowych”, a referaty przeniesiono do innych sekcji.

W sekcji I, w Sali Oratorium Marianum, tematem przewodnim była „Książka i literatura w kulturze narodów”, prowadziła ja prof. Anna Migoń. Obrady rozpoczęła dr hab. Anna Gruca (Uniwersytet Jagielloński) omawiając Drukowane dedykacje w XIX-wiecrnej ksiażce jako źródto do badania kultury ksiażki epoki. Dedykacje, według referentki będące świadectwem życia kulturalnego, naukowego, literackiego epoki, zawieraja wiele interesujących informacji, które pozwalaja na badanie książki w różnych aspektach. Przynosza dane o autorze, współtwórcach książki, adresacie dedykacji i okolicznościach ofiarowania mu książki. Dwa kolejne wystapienia związane były z polsko-łotewskimi relacjami literackimi. Prof. dr Aušra Navickiené (Uniwersytet Wileński) w języku angielskim prezentowała Dynamike publikowania ksiażek estonskich, totewskich i litewskich w pierwszej potowie XIX wieku. Analiza porównawrza (Dynamics of Publishing of Estonian, Latvian and Lithuanian Books in the first half Nineteenth Century: a Comparative Analysis). Próbę przedstawienia obrazu literatury polskiej na Lotwie podjęła mgr Krystyna Puntaka (Uniwersytet Wrocławski) w wystapieniu na temat Diziedzictwo oraz stopien reprezentatywności literatury polskiej na Łotwie w latach 1945-2010. Autorka omówiła przeprowadzone badania statystyczne dotyczące polskich książek przełożonych na język łotewski oraz łotewskich na język polski, analizowała repertuar wydawniczy tłumaczeń. Wspólny referat dr Anny Cisło i dr. Piotra Czajki (Uniwersytet Wrocławski) zatytułowany Ksiaغ̇ka w planowaniu jezykowym na 


\section{Ogólnopolska konferencja naukowa...}

praykładzie polityki państwa irlandækiego przedstawił dr P. Czajka, zwracając uwagę na upowszechnianie literatury i miejsce książki w praktyce planowania językowego na przykładzie dwujęzycznej Irlandii, która to podejmowała próby „deanglicyzacji” i „gaelizacji”, a następnie odbudowy kultury języka irlandzkiego. Kolejny temat Przejściowość komunikacyjna klasycznej kultury arabsko-muzutmańskiej - prayczyny niepetnej interioryzacji pisma omówiła dr Bożena Prochwicz-Studnicka (Uniwersytet Jagielloński), pokazując w nim rozwój kultury tego języka w czasach najdawniejszych, oraz perspektywy badawcze teorii jego piśmiennictwa. Wystapienia w sekcji zakończyła dr hab. Anna Dymmel (Uniwersytet M. Curie-Skłodowskiej w Lublinie) wykładem Ksiażka i jej rola w środowisku duchowienstwa lubelskiego w świetle ksiegozbiorów prywatnych w pierwszej polowie XIX wieku. Propozycje badawcze. Powołując się na źródła (pisma notariuszy miasta Lublina, inwentarze, akta licytacji, testamenty duchownych, inwentarze mienia wymieniające książki, inwentarze księgozbiorów duchownych) dała świadectwo obecności książi i jej roli w kulturze duchownych Lublina tamtego czasu.

Obrady sekcji II („Cyfrowa transmisja kultury pisma i druku”) odbywały się w sali wykładowej IINiB przy pl. Uniwersyteckim 9/13, a ich moderatorem była dr hab. Małgorzata Kisilowska. Wystapienia rozpoczęły dr Elżbieta Herden i dr Ewa Jabłońska-Stefanowicz (Uniwersytet Wrocławski) referatem Obraz polskiego rynku e-booków w swietle wybranych źródet informacji. W swojej wypowiedzi autorki odniosły się do badań Biblioteki Narodowej i Biblioteki Analiz, opartych na różnej metodologii, dotyczących rejestracji publikacji elektronicznych. Celem wypowiedzi było porównanie badań obu instytucji oraz informacji ze stron księgarń internetowych i wydawnictw, by wskazać niekompletność i niespójność dostępnych statystyk. Kolejny wykład zatytułowany Polubic rekopisy $i$ starodruki - wirtualne życie dawnej ksiażki w mediach społecznościowych przygotowały mgr Lidia Jarska i dr Grażyna Piechota (Uniwersytet M. Curie-Skłodowskiej w Lublinie), próbując w nim odpowiedzieć na pytanie: czy media społecznościowe przyczyniają się do wzrostu zainteresowania dawną książką? Odpowiedź jednoznacznie wskazywała, że tak, ponieważ media te cieszą się wielką popularnością i dominują w rozpowszechnianiu informacji na temat książki, a jej przekaz uznawany jest za wartościowy - „lubiany”. Na strony bibliotek, Facebooka itp. zaglądaja nie tylko instytucje, ale też bibliofile, historycy książki i pasjonaci. O mediach społecznościowych i ich wpływie na kulturę książki mówiła też kolejna prelegentka - mgr Magdalena Ostrowska (Uniwersytet Mikołaja Kopernika w Toruniu), która stwierdziła, że media te służą nie tylko do promocji i marketingu obejmującego rynek książki, ale także do tworzenia społeczności, zatem zjawisko kultury 


\section{Ewa Andrysiak, Ewa Obała}

książki należy rozważać nie tylko w skali lokalnej, ale także globalnej. Przeglądu wizerunków książki i biblioteki we współczesnej kulturze cyfrowej dokonał dr Mikołaj Ochmański (Uniwersytet Warszawski) w prezentacji multimedialnej na temat Memy internetowe - obraz ksiażki $i$ biblioteki w oczach internautów jako praykład obecności ksiażki i biblioteki w cyberprzestrzeni. Wystąpienia w sekcji zakończył mgr Adam Flamma (Uniwersytet Wrocławski), który zaciekawil słuchaczy tematem Ksiegi, zwoje i manuskrypty - rola tekstu w grach komputerowych A.D. 2016, podkreślając rolę tekstu w grach z punktu widzenia rozgrywki i kreowania świata wirtualnego.

Obrady w sekcjach kończyły się interesującymi dyskusjami, a podsumowaniem pierwszego dnia konferencji była uroczysta kolacja w Starym Klasztorze w tzw. unikalnym miejscu na kulturalnej mapie Wrocławia.

Drugi dzień konferencji jej uczestnicy rozpoczęli od zwiedzania Muzeum Pana Tadeusza, po czym obrady w tym dniu zaplanowane zostały w sześciu sekcjach, z których trzy miały miejsce w sali Oratorium Marianum i trzy w sali wykładowej IINiB UWr.

Sekcja I („Humanistyka cyfrowa i jej główne tendencje rozwojowe”), pod przewodnictwem prof. Ewy Głowackiej, obradowała w sali Oratorium Marianum. Jako pierwsza wystapiła mgr Marta Špániová (Uniwersytet im. J. Komeńskiego w Bratysławie), prezentując w języku słowackim referat pt. Wybitni pržedstawiciele niemieckiej wspólnoty ewangelickiej ze Ślaska a ich driałalność kulturalna w Bratysławie w XVII wieku, w którym jako przykład żywych i znaczacych kontaktów kulturowych pomiędzy Bratysławą a Wrocławiem, przedstawiła postać Gottfrieda Gründera, wrocławskiego drukarza działającego w Bratysławie. Kolejna referentka, dr Aneta Januszko-Szakiel (Uniwersytet Jagielloński), w wystapieniu Kuratorstwo cyfrowych zasobów w kontekście potrzeb komunikacji naukowej podjęła próbę zdefiniowania określeń «kurator zasobów cyfrowych» oraz «kuratorstwo zasobów cyfrowych», ważnych z punktu widzenia kompleksowego zarządzania cyfrowymi zasobami nauki ze szczególnym uwzględnieniem ochrony cyfrowych danych badawczych. Wydaje się jednak, że dr Januszko-Szakiel nie do końca przekonała słuchaczy przedstawionymi definicjami stanowiącymi ich tłumaczenie $z$ języka angielskiego. Przedmiotem badań dr. Zbigniewa Gruszki (Uniwersytet Lódzki) był Cyfrowy regionalizm jako aspekt badań bibliologicznych. Prelegent na podstawie analizy zasobów elektronicznych z 16 stron WWW wojewódzkich bibliotek publicznych podjał próbę oceny ich rozmiarów, dokonał podziału tych zbiorów ze względu na formę, przedmiot zarządzania, rodzaj gromadzenia i udostępniania, komercyjność serwisów itp. Zaznaczył, że gromadzony w bibliotekach cyfrowych materiał (stare druki, książki, rękopisy, czasopisma, dokumenty 


\section{Ogólnopolska konferencja naukowa...}

życia społecznego, zbiory ikonograficzne, kartograficzne, kolekcje tematyczne i kolekcje regionalne) może służyć regionalistom zainteresowanym lokalną kultura, historia i piśmiennictwem. Profil użytkownika biblioteki cyfrowej na podstawie badań użytkowników dwóch bibliotek cyfrowych: Jagiellońskiej Biblioteki Cyfrowej oraz Małopolskiej Biblioteki Cyfrowej przedstawiła mgr Barbara Morawiec (Uniwersytet Jagielloński, Redakcja „Lustra Biblioteki”) w referacie Identyfikacja usytkownikón bibliotek cyfrowych. Prelegentka odpowiadała na szereg pytań, m.in. Kim jest użytkownik biblioteki cyfrowej?, Co czyta?, Czego szuka?, Jak ocenia biblioteki cyfrowe? Odniosła się także do udostępniania licencjonowanych zbiorów cyfrowych w bibliotekach publicznych; w 119 badanych bibliotekach cyfrowych udostępnia się ponad 3,3 mln licencjonowanych zbiorów cyfrowych, dzięki wykupieniu dostępu do platform z wglądem do e-booków $(3,299,280)$, czasopism elektronicznych $(1,586)$, baz danych (232) i innych zbiorów cyfrowych.

Sekcji II obradującej pod hasłem „Czytelnictwo i czytelnicy w badaniach bibliologicznych” w sali wykładowej UWr przewodniczyła dr hab. Anna Gruca. Panel rozpoczęła dr Maria Przastek-Samokowa (Uniwersytet Warszawski) referatem Niekanoniczne typologie, czyli czytelnicy sami o sobie, omawiała stworzone przez polskich i słowiańskich blogerów typy współczesnych czytelników (nałogowiec, tronowiec, męczennik, myśliciel itp.). Na podstawie przeprowadzonej wśród uczniów ankiety mgr Krystian Tomala (Uniwersytet Gdański) w wystapieniu To (nie) ksiażka. O nietypowych interakcjach caytelnika z. ksiazka $i$ ich konsekwencjach na przykładzie wybranych ksiażek kreatywnych podjął próbę odpowiedzi na kwestię stosunku dzieci i młodzieży do książki, ich zainteresowania książką w ogóle oraz zastapienia tradycyjnej lektury książką kreatywna. Rozważania dotyczące kryzysu czytelnictwa i stopnia jego związku z kryzysem dziecięcej wyobraźni przedstawiła mgr Paulina Osak (Uniwersytet Gdański) w referacie Między wyobraźniq a ksiażka. O wzajemnych zależnościach międy dziecięca kreatywnościa a poziomem czytelnictwa wśród uczniów. Przeprowadzone wśród uczniów i ich rodziców badania pokazały, że spadek czytelnictwa w tej grupie wynika stąd, że czytanie stało się mniej atrakcyjne w obliczu różnorodnych współczesnych rozrywek. Oddziaływanie literatury na swiadomość obywatelska żotnierzy w latach 1918-1939 przedstawił dr Piotr Dobrowolski (Centralna Biblioteka Wojskowa im. Józefa Piłsudskiego w Warszawie). Autor mówił o wpływie książek na proces wychowania i edukację patriotyczną żołnierzy, zainteresowaniach czytelniczych, księgozbiorach bibliotek wojskowych i żołnierskich oraz polityce gromadzenia zbiorów i doborze literatury dla szeregowego żołnierza, a także propagandzie czytelnictwa jako jednego ze sposobów wpływania na psychikę żołnierzy. 


\section{Ewa Andrysiak, Ewa Obała}

Pod hasłem „Nowe formy książki” odbywały się obrady sekcji III (sala Oratorium Marianum), której moderatorem była dr hab. Aneta Firlej-Buzon, rozpoczęła je dr Anita Has-Tokarz (Uniwersytet Marii Curie-Skłodowskiej w Lublinie) wystapieniem zatytułowanym Bajty do zjedzenia - ksiażki kucharskie dla dzieci w przestrzeni nowych mediów. Autorka przedstawiła przykłady książek kucharskich dla dzieci udostępnianych w różnych formatach medialnych: audiobooki, e-booki, kulinarne aplikacje na urządzenia mobilne (tzw. appsy), internetowe projekty kulinarne, kulinarne blogi, gry online, książki kucharskie tworzone na podstawie filmów, książki kucharskie będące elementem globalnych produktów medialnych dla dzieci. Kolejna referentka - dr hab. prof. UŁ Ewa Andrysiak (Uniwersytet Lódzki) prezentowała Kolorowanki dla dorostych jako nowa forme ksiażki, która w Polsce pojawiła się w roku 2015. Autorka omawiała nowy nurt rynku wydawniczego, szeroką ofertę polskich oficyn w zakresie książek do kolorowania dla dorosłego czytelnika, zarówno firm znanych z długimi tradycjami (Nasza Księgarnia, Arkady, PWN) jak i wydawnictw obecnych na rynku wydawniczym znacznie krócej (Olesiejuk, Amber, Sine Qua Non, Kaktus). W wystapieniu pt. »Pałuba« Karola Iraykowskiego - jeden utwór w dwóch ksiażkowych wcieleniach. Studium praypadku mgr Małgorzata Ogonowska (Uniwersytet Gdański) podjęła próbę odpowiedzi na pytanie, jak na odczytanie i interpretację dzieła wpływa jego funkcjonowanie w wydaniu tradycyjnym i hipertekstowym, a także czy nowa forma może być atrakcyjna dla współczesnego czytelnika. O dwóch tendencjach w projektowaniu książki elektronicznej mówił mgr Artur Rogaś (Uniwersytet Gdański) w referacie Zerwanie i mimetyzm. Dwa nurty wspótczesnej ksiażki elektronicænej zperspektywy wydawniczej. Ostatnia w tej sekcji, z tematem „Dziedzictwo literackie Krakowa w przewodnikach turystycznych" wystapiła mgr Marzena Błach (Biblioteka Główna Uniwersytetu Pedagogicznego w Krakowie), która na podstawie analizy treści siedemnastu wydanych w latach 2004-2014 przewodników, mówiła o zawartych w nich informacjach związanych z książką (drukarnie, księgarnie, biblioteki, księgozbiory prywatne) oraz literaturą (kawiarnie literackie, literackie eventy, wzmianki o poetach i pisarzach). Według autorki w omawianych przewodnikach mało jest informacji o krakowskich drukarniach i wydarzeniach literackich. Wydaje się także, że referentka prezentowała nie tylko literackie dziedzictwo Krakowa.

Równocześnie z sekcją trzecią obradowała sesja IV - „Biblioteki w kulturze książki" - pod przewodnictwem prof. dr. hab. Mirosława Górnego. Pierwszy głos zabrał dr hab. Ryszard Nowicki (prof. Uniwersytetu Kazimierza Wielkiego w Bydgoszczy). W swoim wystapieniu pt. Oddziat Biblioteki Narodowej w Bytomin w latach 1956-1999 mówił o działalności wyjątkowego 


\section{Ogólnopolska konferencja naukowa...}

ośrodka kultury książki w Polsce, czyli zamiejscowym Oddziale Biblioteki Narodowej pełniącym funkcję centrali dubletów i druków zbędnych w skali Polski oraz jego udziale w wymianie międzynarodowej. W przededniu jubileuszu 200-lecia istnienia biblioteki na temat Biblioteka Ossolineum w dawnej i obecnej kulturze ksiażki mówił dr Mariusz Dworsatschek (Zakład Narodowy im. Ossolińskich we Wrocławiu). Prelegent podkreślił, iż działalność biblioteczna i wydawnicza prowadzona przez $\mathrm{ZNiO}$ zdecydowały o wyjątkowej roli Ossolineum w świecie książki. Oprócz tego bardzo duży wpływ na tę wyjątkową pozycję miały znakomite zbiory oraz otrzymywane cenne dary. Obecnie $\mathrm{w}$ funkcjonowaniu $\mathrm{ZNiO}$ widać nowe tendencje, wynikające m.in. z cyfryzacji zbiorów, co wpływa na zmiany form uczestnictwa w tradycyjnej kulturze książki. Sytuację bibliotek partyjnych przy miejskich i powiatowych komitetach PZPR na Mazowszu przedstawiła kolejna prelegentka dr Agnieszka Chamera-Nowak (Uniwersytet Warszawski) w referacie pt. Biblioteki i bibliotekarze partyjni na Mazowsqu w latach 1949-1954 w świetle źródet. Ogłoszony przez władze sukces ,akcji bibliotecznej” przeprowadzonej w 1948 r., w wyniku której powstały nowe biblioteki gminne i punkty biblioteczne miał niewiele wspólnego z rzeczywistością. W oparciu o zachowane dokumenty autorka mówiła o prowadzeniu placówek przez niekompetentnych bibliotekarzy (nieopracowany księgozbiór większości bibliotek, brak ksiąg inwentarzowych, brak katalogów i druków bibliotecznych). Panel zakończył dr Rafał Werszler (Uniwersytet Wrocławski) tematem Nowoczesność, ponad traysta lat temu. Zagubione driedzictwo aranżacji - Repozytorium Marii Magdaleny we W rockawiu. Prelegent omawiał ewolucję architektury i wyposażenia Repozytorium, oddanego do użytku czytelników w 1644 r., które zastąpiło wcześniejsze librarium łańcuchowe. Niestety po 1860 r. aranżację repozytorium zlikwidowano. Wydarzenie z XVII wieku dr R. Werszler porównywal do tworzenia w istniejących wnętrzach bibliotek nowych wystrojów, współcześnie mających charakter multimedialny. Pozostaje jednak pytanie dotyczące nowoczesności zastępującej wcześniejsza „nowoczesność” oraz pytanie, czy wszystko należy niszczyć?

W sekcji V, która poprowadziła prof. dr hab. Maria Juda, wystapienia koncentrowały się wokół teorii i historii książki oraz prasy. Pierwszy temat - Szlachecka cay kupiecka? Postrzeganie ksiqżki i autora w Polsce w XIX wieku - przedstawiła dr Teresa Święćkowska (Uniwersytet Warszawski). Celem wypowiedzi było zaprezentowanie badań odnoszących się do dziewiętnastowiecznego konfliktu wartości kultury szlacheckiej i mieszczańskiej. Rozważania oparto m.in. na analizie dokumentów (korespondencji, wspomnień oraz artykułów z prasy i czasopism) dotyczących relacji wydawców z autorami, obejmujących zagadnienie własności literackiej i prawa autorskiego na zie- 


\section{Ewa Andrysiak, Ewa Obała}

miach polskich w dobie Konwencji Berneńskiej. Kolejna prelegentka dr hab. Małgorzata Derkacz (prof. Uniwersytetu Wrocławskiego) omawiała Kształtowanie sie problematyki prasoznawczej w obrebbie ogólnej teorii nauki o ksiqżce (z.warsz̧tatu polskich bibliologów), a szczególnie kwestie dotyczące procesu usamodzielniania się prasoznawstwa - na podstawie prac publikowanych na łamach czasopism z zakresu nauki o książce - oraz pojawienie się problematyki prasoznawczej na łamach czasopism specjalistycznych (prasoznawczych i medioznawczych). Dalej, o Najcenniejszych średniowiecznych kodeksach niełacinskich we wspótczesnych zbiorach polskich, mówiła mgr Kinga Brzozowska (Uniwersytet Wrocławski). Referentka zaznaczyła, iż wśród rękopiśmiennych kodeksów dominują religijne księgi łacińskie, ale w mediewalnych zbiorach można też znaleźć cymelia hebrajskie, ormiańskie, czy staro-cerkiewno-słowiańskie, a wśród bogactwa i różnorodności zbiorów polskich jako przykłady omówiła: ormiański Ewangeliarz ze Skewry (XII wiek), hebrajski Mabzor (XIII wiek), francuską Le Roman de la Rose (XIV wiek) i niemiecki Sachsenspiegel (XIV wiek). Niełatwy i złożony problem badawczy dotyczący dziejów książki polskiej w latach 1945-1989 podjął dr hab. Grzegorz Nieć (Uniwersytet Pedagogiczny w Krakowie) przedstawiając wykład Jak napisać historie ksiażki w Polsce Ludowej? Lata 1945-1989 to okres cenzury i tłumienia wolnego słowa, także czas różnorodnego dorobku wydawnictw i edytorskiego profesjonalizmu, ale też lata słabego rozwoju ruchu wydawniczego i zacofanej poligrafii. Badacz tego okresu staje zatem przed dylematem, z jakimi pytaniami należy się zmierzyć (pytania dotyczące bazy źródłowej i jej dostępności, stanu badań, zastosowania metod czy zwrócenia uwagi na czynniki w panującym wówczas w Polsce systemie politycznym). Próbę refleksji nad problematyką miłości do książki, zwanej bibliomanią, podjął dr Karol Makles (Uniwersytet Śląski w Katowicach). W referacie Miłość do ksiażek. Bibliomania - zarys opisu zjawiska autor zwrócił uwage na różne formy manii książkowych i omówił związane z nią zjawiska.

Sekcji VI, zatytułowanej „Typografia, edytorstwo, rynek wydawniczy”, przewodniczyła prof. UWr Bogumiła Staniów, a obrady w niej rozpoczęła dr Elżbieta Pokorzyńska (Uniwersytet Kazimierza Wielkiego w Bydgoszczy) referatem pt. Introligatorstwo wspótczesne i jego miejsce w zainteresowaniach oprawoznawców. Prelegentka przybliżyła historię introligatorstwa w okresie PRL i w czasach współczesnych (zjazdy, wystawy rzemiosła, cechy komisaryczne, walka z prywatnym rzemiosłem, uspołecznienie zakładów, introligatornie przemysłowe przydrukarniane, szkolnictwo i potrzeby przemysłu, konkursy na najlepiej oprawiona książkę itp.), zaprezentowała wybrane sylwetki polskich twórców i ich dokonania (m.in. Tylkowski, Strusiński), wymieniła publi- 


\section{Ogólnopolska konferencja naukowa...}

kacje poświęcone introligatorstwu najnowszemu, a także przedwojennemu. Kolejne wystapienie dr. hab. Tomasza Bierkowskiego (prof. Akademii Sztuk Pięknych w Katowicach) i dr Ewy Repucho (Uniwersytet Wrocławski) pt. Potrzeba rewolucji. O jakości komunikatón wizualnych wspótczesnych polskich publikacji z zakeresu szeroko pojetej bibliologii $i$ informatologii to dwugłos grafika i bibliologa podnoszący kwestie okładek. Autorzy uświadamiali, jak ważna w percepcji wizualnych komunikatów drukowanych jest ich odpowiednia jakość typograficzna, podkreślili potrzebę zmiany w podejściu do kształtowania okładek wydawnictw w środowisku bibliologiczno-bibliotekarskim. Referenci przedstawili typograficzne przykłady okładek wydawnictw dzieląc je na: niską i wysoką jakość komunikacyjna, pokazując podstawowe błędy typograficzne, łamanie utrwalonych kodów semantycznych, brak staranności, określając niektóre za neutralne, dosłowne lub nieadekwatne oraz dając dobre przykłady estetycznego wizualnego odbioru poprawnie wykonanej okładki. Próbę redefinicji miejsca ekslibrisu w kulturze ksiazżki podjęła dr Agnieszka Fluda-Krokos (Uniwersytet Pedagogiczny w Krakowie), przypomniała liczne jego przemiany na przestrzeni wieków (ewolucja technik graficznych, stylów w sztuce, przejście od elitarności do popularności, utrata pierwotnej funkcji). Tematem wystapienia dr. Pawła Bernackiego (Uniwersytet Wrocławski) była Wspótczesna polska ksiażka artystyczna po roku 1989. Autor nakreślił kilka nurtów eksperymentujących z tradycyjną formą kodeksu i wskazał jej potencjalne kierunki rozwoju, takie jak: liberatura, books-objects, piękna książka. Konferencję zakończył referat dr Kamili Augustyn (Uniwersytet Wrocławski) Uwagi o ksiażce i rynku wydawniçym w esejach wybranych Virginii Woolf. W ciaż aktualne? Prelegentka podejmując rozważania dotyczące książki i jej miejsca we współczesnej kulturze przywołała refleksje angielskiej pisarki (uważanej za jedna z czołowych postaci literatury modernistycznej XX wieku) m.in. na temat form, funkcji, odmian i znaczenia książek $z$ obecną sytuacją na rynku książki i przemianami związanymi z rozwojem technologii cyfrowych.

Z 49 zgłoszonych referatów, wygłoszonych zostało 44. Szkoda z pewnością, że nie obradowała, z powodów niezależnych od organizatorów, sekcja pt. „Kultura książki w środowiskach wyznaniowych”. Z zaplanowanych w niej czterech wystapień, jedno dr hab. Anny Dymmel przedstawione zostało pierwszego dnia w sekcji I, drugie mgr Marty Špániovej w drugim dniu konferencji. Zabrakło natomiast wystapień zgłoszonych przez Tomasza Ratajczaka (Uniwersytet Zielonogórski) pt. Polskie modlitewniki różnych wyznań w XIX wieku (w swietle Bibliografii polskiej Karola Estreichera) oraz Igora Borkowskiego (Uniwersytet Wrocławski) Ksiqخ்a dla zakonnic, ksiazka zakonnic - miejsce i rola biblioteki klasżtornej w ṡyciu wspótczesnych konwentów klauzurowych w Polsce. 


\section{Ewa Andrysiak, Ewa Obała}

Drugiego dnia konferencji nie wystapili: w sekcji I Julita Niedźwiecka-Ambroziak (Biblioteka Wyższej Szkoły Bankowej w Toruniu) - Interaktywny projekt El Quijote jako przyktad zastosowania technologii informatycznych w naukach humanistycznych, w sekcji II Anna Pachowicz (Państwowa Wyższa Szkoła Zawodowa w Tarnowie - Rola ksiażki w życiu emigrantów polskich we Francji w latach 1941-1944, w sekcji IV Andrzej Buck (Wojewódzka i Miejska Biblioteka Publiczna im. C. Norwida w Zielonej Górze) - Biblioteka jako »trzecie miejsce« w perspektywie nowych przestrzeni wybranych bibliotek lubuskich.

W swoich wystapieniach prelegenci poruszali różnorodne zagadnienia związane z kulturą książki, obecnie centralną kategorią badawczą bibliologii, a wieńczące obrady w sekcjach dyskusje wnosily jeszcze wiele ciekawych informacji do wygłoszonych referatów, co świadczy, że w wielu kwestiach tematy nie zostały wyczerpane.

Trzeba podkreślić, że interdyscyplinarna konferencja połączona z jubileuszem Instytutu Informacji Naukowej i Bibliotekoznawstwa Uniwersytetu Wrocławskiego była ważnym wydarzeniem bibliologiczno-humanistycznym starannie przygotowanym przez organizatorów. 